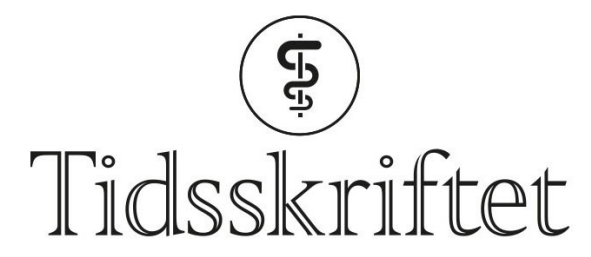

DEN NORSKE LEGEFORENING

\title{
Gittercelle - norsk ord for «norsk» celle
}

SPRÅKSPALTEN

\section{ERLEND HEM}

E-post: erlend.hem@medisin.uio.no Erlend Hem er professor dr.med., fagsjef og redaktør for Tidsskriftets språkspalte.

Norge fikk sin aller første nobelpris i fysiologi eller medisin for oppdagelsen av gittercellene. Enda godt at de har fått et norsk navn.

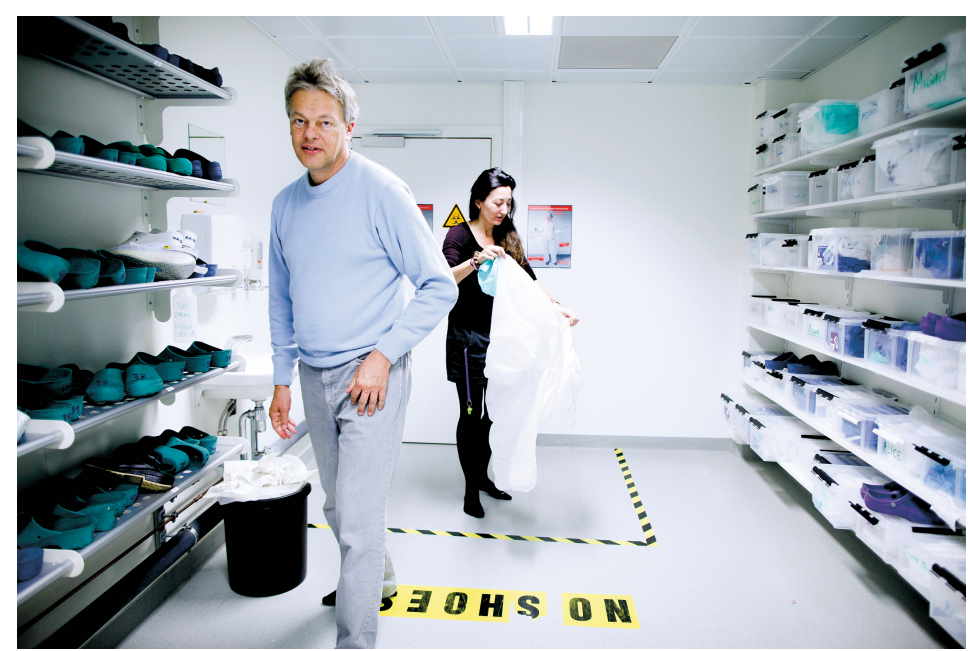

Edvard Moser og May-Britt Moser mottok nobelprisen i medisin eller fysiologi i 2014 for blant annet oppdagelsen av gittercellene. Foto: Monica Strømdahl / Aftenposten

May-Britt Moser og Edvard Moser undersøkte hvordan rotter kan vite hvor de er, hvor de har vært og hvordan de finner frem i sine omgivelser (1). De oppdaget noen nerveceller som var aktive når rottene var på bestemte punkt i buret, og at disse dannet et heksagonalt mønster (2). Disse cellene ble kalt grid cells på engelsk, men hva skulle man kalle dem på norsk? Svaret ble gitterceller.

I mediearkivet Retriever viser det seg at første treff på «gitterceller» i denne betydningen er fra Tidsskriftet i 2007 (3). Det er et eksempel på at en direkte oversettelse fra engelsk kan fungere godt - grid på engelsk kan bety 'gitter'. Da Tidsskriftet omtalte den samme oppdagelsen året før, brukte vi formen gridcelle (4). Men gittercelle bør foretrekkes. Det er godt norsk, og gitter er lettere forståelig enn grid. Oversettelsen har også fått gjennomslag: Det er flere treff på «gitterceller» enn «gridceller» i Retriever.

Danskene bruker også gittercelle, mens man på svensk kaller dem for rutnätsceller, og det gir jo også mening (2). 


\section{Gode norske ord}

De siste tiårene er det oppdaget flere nye celletyper innen det samme fagfeltet. Det er gledelig at mange av dem har fått gode norske betegnelser. Moser og Mosers oppdagelse av gittercellene må ses i sammenheng med den amerikansk-britiske forskeren John O'Keefes oppdagelse i 1970-årene av det som har blitt kalt stedceller (etter engelsk place cells) i hippocampus (5). Stedcellene er aktive når et forsøksdyr bare er på ett bestemt sted i buret sitt. Viktige er også hoderetningsceller (eng. head direction cells), som ble oppdaget av James Ranck i 1980-årene i en annen struktur i tinninglappen, kalt presubiculum (5).

Systemet som gjerne kalles hjernens navigasjonssystem, registrerer også hastigheten som dyret beveger seg med gjennom egne fartsceller (eng. speed cells). Her bruker leksikonet betegnelsen hastighets-nerveceller, men fartsceller er kortere, ligner på det engelske og bør foretrekkes. En egen type nerveceller er kantceller (eng. border cells), som registrerer når dyret nærmer seg en begrensning av omgivelsene, som en kant eller en vegg. Disse beskrev Moser og Moser i 2008 (5).

\section{LITTERATUR:}

1. Lømo T. Nobelprisen i fysiologi eller medisin 2014. Tidsskr Nor Legeforen 2014; 134: 2232-3. [PubMed][CrossRef]

2. Språkrådet. Gittercelle. Aktuelt ord.

https://www.sprakradet.no/Vi-og-vart/hva-skjer/Aktuelt-ord/Gittercelle Lest 22.10.2018.

3. Hem E. Hvordan husker vi? Tidsskr Nor Legeforen 2007; 127: 1483.

4. Bjørheim J. Hjernens navigasjonssenter kartlegges. Tidsskr Nor Legeforen 20o6; 126: 2495.

5. Hassel B. Gitterceller. I: Store medisinske leksikon. https://sml.snl.no/gitterceller Lest 22.10.2018.

Publisert: 23. januar 2020. Tidsskr Nor Legeforen. DOI:10.4045/tidsskr.19.o806

(C) Tidsskrift for Den norske legeforening 2020. Lastet ned fra tidsskriftet.no 